\title{
Science, Technology and the Future of Man
}

\author{
Jerome P. Mbat \\ Department of Philosophy, Faculty of Arts, University of Uyo, Akwa Ibom State, Nigeria
}

\begin{abstract}
Man's knowledge as well as progress in science and technology is becoming recognized in our time as the fundamental preconditions and resources of wealth, interpreted by the purveyor of global economy in terms of economic development. At the same time it is becoming a truism that science and technology generate not only new knowledge towards human wellbeing and progress but also generate new risks, threats and uncertainty to the human race. This paper critically explores the dilemmatic and paradoxical conditions facing modern scientists, and argues that the problems generated by modern scientific and technological knowledge and progress in relation to human life and existence rest not on their results but on their control and proper harnessing for the benefit of man. The paper submits that this can be achieved only when the world starts to play down on materialism and give the application of scientific and technological knowledge a humanistic consideration by giving adequate attention to the values that are timeless in order to bring about the true worth of human kind and reinforce its humanity.
\end{abstract}

Keywords: Science, Technology, Future, human kind, Progress.

\section{Introduction}

Science can be described as a methodically organized search for "truth" and "objective knowledge" about reality and the laws of nature although the issue of whether the goal of scientific enterprise should be "increasing verisimilitude" (Popper, 1989:16) or "increasing problem-solving capacity" (Laudan, 1977) is still being debated by philosophers of science. This explains why Popper characterizes scientific enterprise as an "unending process of conjecture and refutation" (Popper, 1989:51). Thus by implication, any discipline that is systematic, methodical and procedural in the study of nature or reality based on observation, experimentation, measurement, test and the formulation of laws, principles and theories that can explain as well as make predictions about nature can be described as "scientific". Popper has, however, tried to be specific in the issue by saying that the "criterion of scientific status of a theory is its falsifiability, refutability or testability" (Popper, 1989:37).

The aim of science, in this context, presupposes objectivity, most especially, as it searches for truth through the instrument of its methods. In this context, therefore, the fundamental purpose of science is and should be the accumulation and classification of empirically derived experiences and systematization of such experiences into general laws and principles governing the specific categories into which things in the physical world can be classified and studied especially for the benefits of man. These characteristics sustain the claims of science to reliability and objectivity.

The practical application of science as a human activity has affected not only the life and existence of man but also his attitude and thinking about human values such as security, freedom, well-being, human dignity, good health and longevity. It has helped to change man from the "food-gatherer" and "hunter" that he was many centuries ago to an inventor of industrial machines and other artifacts as well as to a manufacturer of industrial chemicals. These achievements have relieved man of much labour and created conducive environment for better and fulfilled life. Under such conditions, man has come to combine his arts and skills or techniques not only in the incremental extension of his capacity to transform nature but also in putting to gainful uses, the gifts of nature to his benefits. These sort of technical processes, as the New Webster's Dictionary of English Language, describes are developed in a vast, but related fields of knowledge such as industrial technology which embrace the chemical, mechanical and physical sciences, as applied in industrial processes (1975:1015). This is to say that science-based technologies involve man's rational faculty in production. They also involve industrial and technical means, processes, tools, machines and ideas in the production of material goods and services for man.

Etymologically, "technology" derives from two Greek words; namely 'techne' (meaning art, craft, skill), and "logos", (meaning "word" - word as expressing an inward thought or knowledge, reason, study or discourse). In this sense, technology refers to a discourse or study on the arts, a systematic study of techniques or regular methods of producing or making things. Technology, therefore, involves the knowledge of human techniques in doing things. Thus at a point it may not, in practice, be easy to separate modern science from technology. However, from our analysis so far, science is fundamentally concerned with the systematic 
application of empirical methods for an unending and rigorous study of nature in its entirety, whereas technology is concerned with the use of scientific knowledge to develop different techniques of producing material things. The historical development and application of these two spheres of human knowledge scientific and technological - have proved through their results to be of tremendous benefits to man in several ways in terms of extending his potentialities to dominate, govern and subdue the world as the 'crown' of God's creation.

The historical development of man's civilization shows that science, and later, technology, are the last two of human ventures; but in spite of their brief period of emergence, they have had tremendous impact on all aspects of man's life and existence. Their by-products are found everywhere around us. These include hospitals, industrial firms, transport and communication systems, electricity and many other things. In addition, science and technology have influenced man's thinking and attitudinal responses more than ever in terms of their promotion of man's desire to know and understand, to appraise evidence objectively, and to be systematic in the search for data and meanings and relations among data as well as in the application of logic for rational conclusions.

\section{The Positive Impacts of the Great Advances in Modern Science and Technology}

Ekong (2006) has defined 'advances in science and technology' as the multifarious scientific discoveries and inventions in the last fifty years of world history which have sent man into the moon and changed man's knowledge concerning his body, his environment and overall existence. However, this definition is not a denial of the historical antecedents of these discoveries and their associated consequences to man's life and his environment, starting even with the invention of gun powder in the middle Ages.

The invention of gun powder saw the beginning of the use of fire arms in regional as well as international wars. This invention had enhanced governments to exert their authority more effectively and to protect their territorial integrity on land and on sea. Today we learn that:

...every gun will have its integral computer which can indicate a magnified day and night view of the target zone. It can ask for the target to be identified on a viewing screen, decide what sort of projectile should be fired, aim itself, make allowance for wind speed and direction, and then fire on command (Gandi, 1982).

Another exciting invention that influenced man's life positively was the invention of mariner's compass which facilitated explorations by land, sea and air especially during the early travels between Europe and America, and between Europe, Asia, India and Africa. As a result different nations and cultures of the world were brought into greater contact which resulted in exchange of ideas and scholarship that increased human knowledge globally.

The steam engine that was invented later marked the beginning of the industrial revolution and automation in Europe. Transportation became much facilitated through the construction of railways. Above all, the industrial revolution of the $18^{\text {th }}$ century brought about increased factory productivity with reduction in manual labour because of the use of new production machines such as robots. Today computers are invented that can calculate, coordinate, translate, correct their own malfunctioning and serve as memory banks. Indeed, in the industrially advanced economies, computers are fast becoming constant companions of school children and housewives, no less than of people in business industries, higher institutions of learning and so on.

Another important landmark made in the scientific and technological civilization is connected with the discovery of electricity which came with the invention of telephone, telegraph and later radio, cameras and television. Indeed, the role of electricity in this sphere is enormous and cannot be overemphasized here. The successful operations of modern producing industries, factories, firms, companies, the emergence of institutions of learning at all levels, markets, offices, motor engines and households, hospitals and so on, all depend so much on electricity supply, without which the increased extension of human capacity to transform nature or the world would be difficult.

Moreover, today our world has been reduced to a small village because of the level of sophistication attained in the manufacture of phones, some of which are so portable and could be turned into computers. Regrettably many nations, especially in Africa and other Third World nations are still confronted with the problem of electricity partly on account of vandalization of installations and partly because their governments are insensitive to this problem although they know how seriously it has affected their economy. Another revolution in science and technology brought about television which also uses electric power extensively to keep us informed of government and other development programmes and achievements, of new ideas and products, of social problems and solution, attitude and actions of people and governments of other nations of the world indeed of global politics and economy. Above all, we now have access to internet; we can now process large capital databases library. 
Significant and exiting also is the discovery of the processes for bringing about the controllable atomic fission and thermonuclear fusion. This discovery has led to atomic reactions which have created radioactive isotopes that are used in the treatment of diseases as well as in industries and agriculture. Indeed it has brought man to the threshold of "unlimited energy supply" (Balogun, 1969:195).

Beside this, science and technology have enabled man to manufacture rockets that facilitate his explorations of the outer space and hence to disclose the mysteries of the planetary system, especially the Moon and Mars and other points of interest without giving serious thoughts to the high cost and the risk to human life. Thus, "Man is no longer restricted to the confines of the earth and its environs. Hitherto he has been a terrestrial animal. But now he is also an extra-territorial animal and very soon a citizen of the cosmos" (Balogun, 1969: 195).

Just a few years ago we heard that the United States NASA was building a series of new rockets (Ares 1 and V) and spacecraft (Orion, Altair), together known as "Constellation" to convey humans into orbit and to the Moon from the International Space (ISS), that was scheduled to be completed in 2010. Not only the United States is found in this race, Russia (The Soviet Union), China, India and even Japan also participate today in the "space race", making similar spaceflight plans to land humans on the Moon within the next twenty years. In fact the current report from NASA is that:

The shuttle has carried more than 320 people aloft over $65 \%$ of those ever to fly in space and has expanded the ability of people to live and work in space. 25 missions with components from the international Spacelab were flown between 1983 and 2000, utilizing instruments pallets and a lab module built by the European Space Agency.

In addition to the primary objectives which include exploration (human as well as robotic), national pride and international prestige and international leadership, United States of America has also the secondary objectives such as advancements in science, economic development, new technologies and education, all of which constitute the rationales for the US government - funding human spaceflight project without minding its ambitions nature, high cost and the inherent risk on human life.

Importantly too, the United State believe in accomplishing this leadership task/programme by remaining committed to its existing international partners, including Russia, India and China, the newest space nation, irrespective of the current situation of non-cooperation between United States and China. The logic of the "space-race" as gotten online is that:

By sending people into places and situations unprecedented in human history, nations aim to expand a global definition of humanity in their own image. The benefits to a country being represented in this way have generally justified the risk and cost of human life, such as military service to a nation is deemed worthy of such sacrifices.

But I see some flaws in the last part of this argument. Man's life is highly priced and his dignity and humanity cannot be exchanged for material benefits. Moreover, the argument makes a wrong comparison between the risk involved in military service and the risk involved in space exploration. While it may be expedient for a nation, after exploration of all peaceful means have failed, to risk human life in military service as a necessary requirement to stop external aggression, protect and preserve life and property to ensure human existence, the latter does not require space exploration and therefore risking human life in its pursuit is not, and should not be seen as a worthy adventure. Thus, the adventure of space exploration raises an important moral question of risk on human life and the economic question of huge investment (\$100 million approximately) by the US government on something that is not of general benefit. Again the future of "space race" with America assuming the leadership role is very unpredictable should a "Cold War" repeats itself. It is feared that if this happens, the "space race" phenomenon will encourage competition rather than cooperation among the present participants in the race.

Besides these advances made in the physical sciences, and their accrued benefits, great advances have also been made in the biological, physiological and psychological sciences, which indeed have also impacted negatively as well as positively on man although the positive impacts are incomparable to the negative impacts. It shall be clear later that the biological sciences and technologies have impacted more on man's life and existence than the physical sciences in so far as the basic problems of mankind are biological in nature, such as overpopulation and under-production of food and organic raw material, and so on. These have resulted in hunger and poverty in many parts of the world and which has now become a global concern.

The application of medical knowledge and scientific techniques has relieved man of pain by using anesthetics, antibiotics and other medicines and drugs. This knowledge has lengthened the life-span of man as well as helped in the production of artificial (cloned) kidney and heart for kidney and heart transplants; the control of the size of human family is possible through "family planning". The subject of heredity and artificial 
insemination (in vitro fertilization) that spares women of barrenness, the production of test-tube babies and the practice of egg donation, sperm banking and surrogate motherhood are also now possible through the knowledge and application of medical (biological) sciences and genetic technologies. Although all that I have presented above as welcome advances in science and technology, with their positive impacts, may not be exhaustive; they, at least, have given us an insight into the contributions of science and technology in human civilization and wellbeing. However, there is also need to explore the undesirable effects of the application of science and technology to mankind. This is expected to uncover most of the risks and dangers that confront the modern man in his attempt to foster his advances in science and technology on account of his abuses on science and technology.

\section{The Horrors of Science and Technology}

A close examination of man's knowledge and practice of science and technology shows that none is intrinsically totally good or bad. Rather it is their applications for the purpose of problem solving that make them either good or bad, just or unjust in relation to man's total wellbeing, now and especially, in the future. In this section let us reflect on some of the problems created for man by his advances in the physical, chemical and biological sciences and technologies. Before this, let us look at man's general attitude towards materialism, which we consider to be the bedrock of the mad surge in the pursuit of all possible aspects of science and technology, so named.

It is an accepted fact that today the results of scientific and technological studies have impacted greatly in almost all the nations of the world. The impact, I believe, will be more felt in the scientifically and industrially advanced economies of the world, like Europe and America than in the developing economies, such as the African nations and other Third World economies. Among the general claims of the positive contributions of science and technology to man's life is that of mass production of material goods, including food and services for man. This is typical of the industrialized economies where agricultural technology, especially genetic technology, has made it possible for man to produce more genetically modified seeds than the immediate food needs of their national population growth. The same advances have been witnessed in manufacturing nations. In managerial services, scientific knowledge and technological applications, have also promoted improved skills, resulting in higher and improved services.

But while it cannot be doubted that science and technology have improved the levels of material production of goods and services - qualitatively and quantitatively - for man's consumption and wellbeing, the advancements in these fields have infringed greatly upon the dignity of man by institutionalizing materialism. The explanation is that science and technology in history have tended to elevate and emphasize only the material aspect of the human life while neglecting his very personality which is superior and higher and, therefore, demands respect. The result is that; "the man of the scientific and technological culture becomes a truncated man - a half-man, even worse than a half-man - a man of the inferior-half-a-matter-man" (Nwoko, 1992:112).

The contemporary man becomes so lured into believing that all there is, is nothing over and above matter. Thus for him, the primary goods are material values, which through technology are elevated and promoted, while the spiritual personality and value of man become elusive and subordinate to matter. Understood in this context, human problems are erroneously understood to be essentially material and therefore must require only material solutions. This may be reduced to the doctrine of "scientific and technological materialism", which is propagated jealously, especially, by the Western capitalist economies within the context of today's globalized economy, which defines the material wealth of any nation in terms of economic growth, while concealing the exploitation and inequity that characterize participation in global economic race. The explanation is that there is glaring imbalance and inequity in global economic venture. It is bait thrown, most especially, to the developing and the Third World economies, described by the purveyors of global economy, as "those that need economic growth". Of course, this is still a neo-colonial strategy by the purveyors of global economy and their governments to sustain their foreign domination of, especially, African and other Third World nations. The whole venture of global economy boils down, in this perspective, to economic dishonesty exhibited by the political and economic world "super-powers" over the developing economies with the hidden view of subjugation which is basically an infringement of human right at the international arena. It would be false to believe that Europe and America are ignorant of the negative chain effects of such a violation. Rather, they are blinded by their uncritical pursuit of materialism. In such a circumstance, the crucial question is: where does the hope of the economically disadvantaged nations lie in globalized economy, which indeed, has also greatly affected global politics and decision making?

The problems of man as a consumer of scientific and technological products in relationship to his destiny as a "person" can be interpreted not only as the question of morality of "right appetite" but also as that of "human right", which Nwoko (1992) has tried to link to his notion of "right reason" of man, to the extent that a genuine and right human choice is to be judged from the standpoint of its conformity with "right appetite" (144). Understood from this perspective, a good human choice should be determined by how much, a person's 
choice corresponds to his human rationality - a choice guided by the dictates of critical thinking or reason. Regrettably, the modern man, in his pursuit of scientific and technological progress does not seem to be guided, most of the time, by the dictates of reason. The result is that he, most of the time, commits errors and is even sometimes in a dilemma in choosing what to produce as well as what to consume. Thus, if man, the consumer of scientific and technological products, must focus on his rational end in life, then he must be prudential in making choices. He must cultivate the "virtue of prudence" described as "the virtue that ensures that man will easily select the right means in order to perform acts that will lead to his end as man" (Grindel, 1964:194).

The simple inference is that the grip of materialism, and hence, of consumerism assumes a negative sway in the individual person when his or her desires are not guided by right reason in his application and use of scientific knowledge and technological goods and services towards the realization of his or her ultimate end. Thus unless humans cultivate only the right appetite, the uncritical urge for materialism, promoted by science and technology, will continue to cloud their mind, creating a barrier for the full realization of their rational ends. In order to make the best out of his world, man must therefore, be dispassionate in his pursuits of materialism because his nature and needs, as humans, go beyond the demands of materialism. This is so because humans are credited with "right appetite" only when their desires for material goods and services are in conformity with their rational nature. This is why Socrates, the ancient Greek philosopher, said, "man know thy self".

Our today's world needs to de-mystify our tendency towards materialism in terms of irrational accumulation of wealth which results in the stratification of our world today into "developed" and "developing" economies with their associated problems. Indeed, being a brain-child of the capitalist economy, materialism is the root of much of the evils which our world today has experienced. Thus if the nations of the world, especially, the world economic "power-brokers", can control their cravings for materialism, and also focus on the spiritual and moral aspects of their societies, much of the troubles in our world would be reduced appreciably. The world super-powers, for example, would start withdrawing from their unsociable interest of domination of other nations' politics and economy so that their tendency to incite nations into wars against one another for their concealed purpose of creating an arena for testing the efficacies of, and markets for their destructive weapons of warfare, may be, at least, reduced or eradicated, if possible. Indeed, it cannot be denied that the whole of Europe and Soviet Russia were dragged into the battle field in the world wars I and II (1914 1945) by their materialistic spirit in order to decide their powers of territorial expansion and domination. Of course, they did that with disregard to the millions of human beings that lost their lives and the huge destruction of property. This immediately reminds us of the most ghastly incidence of inhumanity displayed not only by the use of atomic bombs, but the destruction of the six million Jews in the gas-chambers by the German "warmonger", Adolf Hitler. And other dehumanizing factors of these two wars included, not only the conscription of natives of the invaded and plundered territories by military expeditions of the invaders into their armies, but also the casting of the burden of maintenance of their troupes upon those invaded territories. All these were encouraged by the quest for materialism promoted by science and technology as the invaded territories were turned into plantations that produced raw materials to serve the home industries of the invaders. Exploitation of this nature amounted to nothing other than dehumanization. Let us now look at the aftermaths of scientific and technological culture on man.

\section{The Status of Man, the Worker, in the Scientific and Technological Culture}

The situation still remains precarious for man when we look at man, the worker, the creator of science and technology, within the scientific and technological culture. Within this culture, man still emerges as the victim of his inventions. This experience, therefore, raises the question of the rationality of the culture itself for man, for if it (scientific and technological culture) results from man's labour, skill and thought, then it should be subservient to man. It should offer material security for man as well as promote other indispensable human values such as human dignity, autonomy and wellbeing in order to promote man's status in the society. It should be a channel for the development and expression of his talents and should promote good human relationship and condition of life towards his full self-realization as rational conscious being. Above all, it should respect the value of man across the nations of the world. At least, the Marxian-Engelian economic theory concedes that labour contributes to the evolutionary development of man. Unfortunately the adverse effects of scientific and technological culture on man have become a recurrent phenomenon in history, especially in its factory and industrial operations.

In these operations, although man's labour, skill and thought are effectively utilized for large scale production, he emerges as a victim of production. In most cases man, the worker is coerced, forced to work at his own risk or even destruction, just for the purpose of achieving the material end of large scale production of generation of further large capital and of keeping him perpetually economically dependent on the system. The implication is that, if the economic motives - effective utilization of labour, mass production, maximization of capital and the economic dependence of the worker on the system - are uncontrolled, then the tendency will continue to be, as it had most of the time been in history, to force the worker to serve these aims, no matter the 
conditions. He would be subjected to servitude by factory in order to satisfy its project of technological production, while at the same time remaining impoverished by being made perpetually dependent on the productive system. And under such a condition, his progress in life is stifled. The explanation is that: ... under the factory system all elements of production which can be turned into capital become crystallizing centres for further profits on capital while for the worker there remains only the stipulated wage (Bucher, 1901:150).

Karl Marx (1977), at the end of Das Kapital, discussing the problem of "surplus value" and the problem of alienated labour, gave a clear picture of the predicament of the worker within the scientific and technological culture. Marx sees modern techno-production system in its present persuasion essentially as being reduced to automation. Indeed the opinion of most scholars today is that automation should be equated with modern technology. "Automation" here, is explained as the increasing use both in offices and factories of various types of labour-saving equipments having virtually continuous, and in some instances, self-regulating operation.

Although automation may be accepted as an evolutionary stage of man's mode of work, resulting from his advanced knowledge in science and technology and as a turning point to a higher skill, it challenges man's formal skill more than material skill. This is so because:

...the more mankind is compressed upon itself by the effect of growth, the more, if

it is to find room for itself, is it vitally forced to find continually new ways of arranging its elements in the way that is most economical of energy and space (de Chardin, 1974: 98).

Thus man is seriously challenged to pre-empt the future needs in automation - technology in order to develop new and more developed attitude towards labour. Today, the awareness is growing in many universities in the developing nations, for example, to establish and develop the department of computer science and related sciences. This is done in order to meet up with the problems facing the production sector (industries) and offices that depend mainly on automated machinery. This has forced many societies to see the need for advancing their system of education in order to meet with their growing scientific and technological developments and other related needs.

Yet automation as considered in this paper has its serious setbacks on man, the worker, and producer of production equipments, in terms of the unemployment and associated problems it has created for man. This expresses a condition of redundancy by which a worker's contribution to labour is overtaken by the use of modern machines, and his skills - practical as well as intellectual - are wasted. This condition exposes him to many social difficulties including economic and psychological insecurity. Economic insecurity arises because his source of income is no more. Psychological problem arises because under this condition his personality ("ego") is seriously deflated. This happens because the channel and opportunity of displaying his talents and sense of service to human kind is forced into oblivion. Worse still, he develops a sense of social insecurity because he has also lost those good opportunities of relating with his co-workers in terms of sharing ideas with them; he may even become schizophrenic. We, in Africa, and especially in Nigeria, are witnesses of the social evils created by unemployment and poverty, especially, among our youths and parents retrenched from jobs by public and private sectors of our economy. These ranges from armed robbery, human trafficking, kidnapping and other forms of violence and criminal acts which make man's life commodious and unsafe.

Beside, even when man is still at work within the scientifically technological culture he is most of the time faced with the personality problem of anonymity because, the nature of social relationship encouraged in technological production system is always so artificial and mechanical. The life style of workers tend to be determined by the given industrial structure to the extent that work becomes monotonous as each worker is limited to the same tool and motion such that he becomes de-personalized as long as he is, "shaped by his work, used by it, mechanized and assimilated... and have been deprived of initiative and responsibility" (Ellul, 1964:396).

However, when we examine man's effort to study the physical reality of nature in order to reveal its secrets and turn them to his benefits, we find man creating more complex problems for himself. The next section, therefore, leads us into another problem which man creates for himself by his pursuit of nuclear technology through his study of nuclear physics, thus "today there is a spread fear all over the world that man has unleashed tremendous natural forces from the atoms that these threaten to swallow him up (Nwoko, 1992: 142).

\section{The Problem of Nuclear Technology Research and Application}

The fear of the possibility of man being swallowed up by what he invents, is a genuine one because he is quite knowledgeable of both the destructive nature and social values of his invention. But in such a situation what do we expect from the nuclear scientists and technologists, the world over? Should they continue their professional activities on account of the instrumental good or value associated with their inventions or should 
they refrain from such researches on account of the catastrophes they can bring on man? The possible way to counter this dilemmatic situation is to look at the problem from a different perspective. If the applications of nuclear science and technology can be both good and evil, then the problem facing man is not whether to continue or to stop his researches in this sphere; it is rather that of control of the unbridled race in the perfection and stockpiling of nuclear weapons and correct harnessing of his sophisticated technological products for the achievement of the highest good; i.e. for the service of mankind.

But the issue of control and correct harnessing of nuclear products does not seem to be an exclusive business of the producers - the nuclear scientists and technologists - but also of the governments that sponsor their researches and invention. It is becoming glaring that some nations of the world are distinctively addressed as the "super-powers", because they command the economic, political and military powers of the world; their political and military strength rest in their possession of top trained military personnel and most destructive and offensive weapons of war-fare.

All attempts made through coalitions of the world super-powers and of the less advanced nations of the world, through the emergence of international organizations to control, most especially, the "power-drunk" governments of the technologically and industrially advanced economies, to control the use of nuclear and biological weapons of warfare, which are essentially genocidal, have proved abortive. And there seem to be no end to the production of such technologically sophisticated weapons, in so far as the quest for territorial expansion and domination, the abuse and infringement of human freedom and human right and the resulting conflicts remain uncontrollable.

Those who are familiar with the Hiroshima incidence of August 6, 1945 mentioned earlier, where atomic weapon was used during the World War II to destroy millions of human lives and property would wonder whether the warring nations in the world today have learnt any lesson from the past at all concerning the insistence on the use of nuclear and biological weapons on one another. Whatever might be the causes of wars among nations of the world today, the parties involved should appreciate the global rights of humanity above the parochial values of individual nations. The use of such destructive weapons should be ruled out in our world. Nuclear researches should be done from humanistic or anthropological perspective. The explanation is that the nuclear scientists and technologists owe humanity the social responsibility not only of the exploration and exploitation of the richness of nature for the good of man, but also the moral responsibility to protect humanity from facing the dangers of immanent destruction, thus ensuring man the opportunity of full self-realization.

However, man seems to be eluded of any hope of continued existence since he discovered atomic bomb. We are hearing about bomb explosions everywhere in the world today especially by terrorists or military expeditions. In Nigeria recently, the phenomenon of suicide bombing is experienced in large populated cities and even in churches carried out by Boko Haram sect while the advanced employment of nuclear energy and the products of nuclear technology have heightened the level of the risks and dangers posed by nuclear explosions. Advanced studies in genetics have likewise brought about biotechnology with its complex problems for man.

\section{Implication of Biotechnology for Human Existence}

In this section I will first discuss briefly the implications of cloning technology which is regarded as one of the breakthroughs in genetic engineering (GE). I want to look, in particular, into the moral implication of extending the same manipulative methods used in replicating and the transplants in plants, and animals to human species. Bert Visser (2001:9), defines biotechnology as "any technological application that uses biological systems, living organisms, or derivatives to make or modify products or processes for specific use"; while Esenowo (2000:1) defined it as "any technology that is used to make or modify the products of living organisms in order to improve plants and animals, or to develop useful micro-organisms".

These technologies which are classified into three processes - "recombinant", "reproductive" and "therapeutic" cloning - in themselves, are all dependent upon new and sophisticated researches in biomedical and biological sciences such as biochemistry, molecular biology, genetics, and so on, where the use of cell and tissue culture and cell fusion are prevalent. They also depend largely on the availability of capital and skilled human resources. It is these new enabling factors that have turned biotechnology, into a specialized enterprise and private researches funded by the capitalistic multinational companies. And it is the implications of this new trend in biotechnology and the perceived problems, especially the risks involved that have raised the moral concern for our discussion.

The issues of cloning of whole human beings and human embryos and the use of human subjects in biomedical researches, especially in laboratory experiments and (GE) have come under debate, most especially, among contemporary ethicists and religious leaders, who have challenged these technologies. The argument has been that, in accordance with their nature and purpose, natural value and environments, plants, animals and human beings ought to be treated differently by modern scientists and technologists as they belong to different levels of created beings. Thus the results of extension of cloning techniques to man have brought more harm 
than good to human beings since they constitute serious threat to man's dignity, rights as well as continued existence on earth.

Although cloning technology has been recognized as a major breakthrough in modern biotechnology, the biomedical scientists and gene engineers, the workers in the biotech companies and governments who sponsor them must address its evils on man urgently and adequately. The point is that, although its application in the production of crops and animals may be accepted by most people as a welcome innovation perhaps for the purpose of producing larger quantity of food in order to feed the teeming populations of the world, granting that the products of such processes are safe for human consumption. But the basic questions are: should humans be cloned? Of what moral use(s) are human and even cloned animal to human welfare, existence and place in the scheme of things? Do clones have same place in the scheme of things in nature as real human beings? Is an asexually produced new life superior in nature and function than sexually produced human life? If not, what is the rationality of cloning technology as a profession, if it creates more problems for human society? What moral justification, if any, is there for the use of clones and cloned organs and tissues for transplants in human bodies when cloned organs could be replaced by human organs whenever need arises and hence, escape the risks and other residual problems of complications, arising from either organ or tissue rejection or infection or all of these combined during the processes of cloning and transplant? How will the biotechnologists remove the danger that the techniques, when applied to human beings, may result in the manufacturing of monsters, cripples, imbeciles and other psychological and physiological disabilities?

Although some scholars may hold that the biomedical scientist should not be concerned with morality in their profession as scientists, the scientists working in the biotech laboratories must be challenged for reducing human species to the level of animal. Although biologically, man has been classed as animals, he is a higher form of animal endowed by his creator with a conscious mind and rationality. Hence, the possibility is there that his cells and organs will react to the different chemicals used by the biotech scientist on animals at the different stages of cloning. Thus the adverse effects of such chemicals are indeterminate, especially in the formations and eventual functioning of the human brain, bones, heart, liver, kidney, eyes and so on. The chemicals may cause all sorts of physical and mental disabilities and malfunctioning, which could eventually be transmitted as traits to future generations, and the chain effects of which may be both unbreakable and unpredictable.

Thus, while we may admire the contemporary biomedical scientists and technologies in general, and gene engineers in particular, for the advancement and potentials they have shown so far, the goal they assign for their practice - providing an unlimited source of organ transplant to any patient whose natural parts are defective - is suspect. Even their artificial means for achieving their projected goal should also be carefully screened as they may not be synonymous with "medical care and respect for human dignity, right and life", which incidentally constitute the crux of the "ethics of medical care". The fact, that cloned embryos are meant for the harvesting of organs and tissues that are eventually sold at very high cost by the biotech companies makes their utilitarian argument of producing surplus organs and tissues for the greater number of patients that might need transplant, also suspect. The selfish pursuit of fame and maximization of economic profits make their deliberate choice of cloning project more controversial and suspicious than the biotechnologists themselves expect. Clinically, the duty, which the medical scientists owe to the society, is to use all his talents and knowledge to improve the quality of human life through health care delivery in ways that do not violate any sphere of human dignity.

The activities of the biomedical scientists and technologists, can therefore be better designated as "achievement centered" to the extent of dehumanizing mankind by reducing them to mere objects that can be disposed of at will after subjection to experimentations, just as they do to animals and artifacts. In Kant's interpretation (1959:53), this amounts to nothing over and above "treating humans as means to ends" or "as animals". Moreover, the biomedical scientists have failed to regard their activity as a social function within the context of the related concepts of "duty", "obligation" and "human dignity" which in effect, meaningfully and ultimately relate humans with nature rather than alienate them from nature. From this perspective it is wrong "to regard rational beings merely as one kind of valuable things among others but rather as beings whose values must be absolute and not comparable to the value of anything else" (Kant, 1963:39).

The world must therefore seriously challenge any science and technology that fails to respect the dignity and inalienable rights of man, for science and technology have meaning for man only within a moral context. We can classify the technologies affecting fertilization and development of human embryo under what is known as "procreative technologies". Man generally, is now able to control his rate of reproduction through the use of various contraceptives which usually are free of charge or highly subsidized. This, no doubt, has been facilitated by technological breakthroughs in drug and chemical researches and manufacturing, and medical instruments. But innovations such as this represent a transition from natural to social choice. This has generated a situation of zero population growth in some European countries leading to the "graying" of the population (Ekong, 2006:91). These kinds of practices encouraged by today's science and technology pose certain 
constraints to man in reflecting on what may happen in the future to him, since he has now turned a murderer, in his attempt to control population growth. We see man here as leading a life of contradiction, whereas God, at his creation had blessed man with all that it takes to increase and multiply and replenish the earth.

There are two other modern technologies that are worth mentioning briefly which also, disturbs especially, the humanist's mind namely, "sonogram" and "amniocentesis" technologies. In the past, couples had to wait till birth to know the sex of their baby; today, prenatal sex identification is made possible through "sonogram" technology. Likewise what is called "amniocentesis technology" has made it possible to discover structural or chromosomal abnormalities in babies before birth. Thus, these technologies present today's couples and the society with new ethical and legal dilemma of whether to have the handicapped baby or one with disfavored sex, to be born or to abort (Ekong, 2006:91). Whatever arguments might be offered for abortion, the position of this work is that abortion at any stage of pregnancy is nothing other than the termination of human life. Thus neither its moral acceptability nor its legalization by persons, group or society would make it right or just. The foetus has a right to life and growth to full self-realization. Moreover, the act remains wrong in so far it cannot be universalized.

\section{Conclusion}

The problems of science and technology in relation to human life and existence as we have analyzed and discussed are not about their results but that of their control and proper harnessing for the benefit of man. While a person may agree that weapons of warfare should be produced by man, that researches in biomedical sciences and technologies should be made use of by man, their application on man should be from the humanistic perspective.

Artificial creation of humans could not have been, and is nowhere considered as part of the divine injunction for man to "increase and multiply". This adequately explains the Divine Supreme intelligence in creating the first man and woman to effect procreation. If this is correct, then what other purpose or motivation does man have in attempting to usurp God's creative power or activity over and above self-indulgence and materialism, which undeniably, are the root of evil in our world? The moment the world starts playing down on its pursuit of materialism, then man will emerge as a new creation backed up by his knowledge of science and technology towards his full self-realization. Then only shall the meaning of "human civilization" and the rationality of science and technology be less questionable.

\section{References}

[1] . Balogun, T. A. (1969). "The Role of Science and Technology in National Development", in Philosophy for Nigerian Education, edited by Adaralegbe, A. Ife: University of Ife Press.

[2]. Bucher, K. (1901). Industrial Revolution. Trans. S. M. Wickette. New York: Henry Holt \& Co.

[3]. De, Chardin, T. (1974). Man's Place in Nature, New York: Fontana/Collins.

[4]. Ekong, E. E. (2006). Sociology of Health and Medicine, Uyo: Dove Educational Publishers.

[5]. Ellul, J. (1964). The Technological Society. Trans by J. Wilkinson, New York: Vantage Books.

[6]. Esenowo, G. I. (2000). Elements of Biotechnology, Uyo: Bonic Printing and Publishing Co.

[7]. Grindel, C. W. (1964). "Is Science Enough?", in G. F. Mclean (ed.) Philosophy in a Technological Culture, Washington D.C: Catholic University of America Press.

[8]. Kant, I. (1963). Foundations of the Metaphysics of Morals. Trans. Lewis White Beck. Indianapolis: BobbsMerril.

[9]. Kant, I. (1963). Lectures on Ethics. Trans. Louisinfield. New York: Harper and Row.

[10] Marx, K. (1977). Das Kapital, Vol. 1 ch. Vii, sec. 1, London: Lawrence \& Wishert.

[11]. Nwoko, M. I. (1992). Philosophy of Technology and Nigeria. Owerri: Claretian Institute of Philosophy Press.

[12]. Lorimer, L. T. \& et al. eds. (1975). The New Webster's Dictionary of English International Edition.

[13]. Visser, B. (2001). "Biotechnology: A Basket of Opinions", in External Input and Sustainable Agriculture (EISA), Vol. 17(4). 